\title{
Hedonik ve Faydacı Tüketim Eğiliminin Plansız Satın Alma Davranışı Üzerindeki Etkisi: Bir Araştırma
}

\author{
DOI: $10.26466 / o p u s .474486$
}

\section{Zehra Türk $^{*}$}

* Öğr. Gör. Dr., Muğla Sıtkı Koçman Üniversitesi, Marmaris Turizm MYO, Muğla/Türkiye E-Posta: zehraturk@mu.edu.tr ORCID: $\underline{0000-0002-0769-1620}$

\section{Öz}

Tüketiciler satın alma kararı verirken bazen duyguları ile hareket etmekte, bazı durumlarda ise faydact ve rasyonel davranmaktadırlar. Tüketicilerin gerçekleştirdikleri alışverişler her zaman planlı olmamaktadır. Alışveriş esnasında daha önceden satın almayı planlamadıkları ürünler ile ilgili ani karar verip plansız satın alma davranışında bulunabilmektedirler. Bu çalışmada, tüketicilerin hazcı/hedonik tüketim eăilimleri ve faydacı tüketim eğilimlerinin plansız satın alma davranışları üzerinde ne kadar etkisinin olduğu araştırılmaktadır. Bu amaçla tüketicilere yönelik alan araştırması gerçekleştirilmiş, hedonik ve faydacı tüketim eğiliminin plansız/ani satın alma kararlarında ne kadar etkili olduğu tespit edilmeye çalışılmıştır. Araştırma Muğla'nın Marmaris ilçesinde gerçekleştirilmiştir. Araştırmaya 317 tüketici katılmışıı. Araştırmanın amacına yönelik geliştirilen hipotezlerin test edilmesinde, korelasyon ve regresyon analizi kullanılmıştır. Araştırma sonucunda hedonik ve faydacı tüketim eğilimi ile plansız satın alma davranışı arasında pozitif yönlü ilişki olduğu tespit edilmiştir. Ayrıca çoklu regresyon analizi sonucunda, hedonik ve faydacı tüketim eğiliminin plansız satın alma kararlarında \%45 düzeyinde etkisinin olduğu sonucuna ulaşılmıştır. Hedonik tüketim eğiliminde olan tüketiciler, faydacı tüketim eğiliminde olanlara göre daha fazla plansız satın alma davranışı gerçekleştirmektedirler.

Anahtar Kelimeler: Hedonik Tüketim, Faydacı Tüketim, Tüketici Davranışı, Plansız Satın Alma Davranışı

OPUS (c) Uluslararası Toplum Araştırmaları Dergisi-International Journal of Society Researches ISSN:2528-9527 E-ISSN : 2528-9535

http://opusjournal.net 


\title{
The Effect of Hedonic and Utilitarian Consumption Tendency on Impulse Buying Behavior: A Research
}

\begin{abstract}
The consumers act sometimes with feelings when making a decision for purchasing, in some cases they are treating pragmatic and rational. The purchases made by consumers are not always planned. They can make an immediate decision about the products they have not planned to purchase beforehand and have an impulse buying behavior. In this study, it is investigated how much influence on impulse buying behavior of hedonist/hedonic consumption trends and the utilitarian consumption trends of the consumers is. For this purpose, field research for consumers has been realized and it has been tried to determine how effective the hedonic and utilitarian consumption trends on impulse buying decisions is. The research was carried out in Muğla, Marmaris. 317 consumers participated in the study. Correlation and regression analysis were used to test the hypotheses developed for the purpose of the study. As a result of the research, a positively relationship has been determined between hedonic and utilitarian consumption tendency and impulse buying behavior. Also as a result of multiple regression analysis, it has been reached end of having the level of \%45 effect on impulse buying decisions of the hedonic and utilitarian consumption tendency. Consumers with a tendency to hedonic consumption perform more unplanned buying behavior than those with tendency to utilitarian consumption.
\end{abstract}

Keywords: Hedonic Consumption, Utilitarian Consumption, Consumer Behavior, Impulse Buying

OPUS @ C Uluslararası Toplum Araştırmaları Dergisi-International Journal of Society Researches ISSN:2528-9527 E-ISSN : 2528-9535

http://opusjournal.net 
Hedonik ve Faydacı Tüketim Eğiliminin Plansız Satın Alma Davranışı Üzerindeki Etkisi: Bir Araştırma

\section{Giriş}

Tüketiciler alıveriş yaparken duygularının etkisi altında kalabilmektedir. Duygulara hitap eden ve tüketicileri heyecanlandıran, onlara haz veren ürünler, satın alma eğilimlerinde etkili olmaktadır. Bu durum literatürde hedonik tüketim olarak değerlendirilmektedir (Coley, 2002, s.33). Tüketiciler her zaman duyguları ile hareket etmezler ve rasyonel davranma eğilimindedirler. Alışveriş esnasında ürünün kendilerine sağlayacağı faydayı dikkate almaktadırlar. Bu tarzdaki tüketici eğilimi ise faydacı tüketim olarak adlandırılmaktadır.

Alışveriş esnasında tüketiciler, daha önceden almayı planladıkları ürünler dışında ani karar vererek de satın almayı gerçekleştirmektedirler. Tüketicileri plansız satın almaya iten etkenlerden hedonik/hazcı tüketim eğilimi ile faydacı/rasyonel tüketim eğiliminin ne kadar etkili olduğu bu çalışmanın odak noktasını oluşturmaktadır.

$\mathrm{Bu}$ makalede hedonik ve faydacı tüketim ile plansız satın alma davranışı arasında nasıl bir ilişki olduğu ortaya koyulmaya çalışılmaktadır. $\mathrm{Bu}$ amaçla makalenin ilk kısmında hedonik ve faydacı tüketim ile plansız satın alma davranışı kavramları açıklanmaktadır. Metodoloji kısmında ise, alan araştırması sonucu elde edilen analiz bilgilerine yer verilerek araştırmanın amacına uygun olarak geliştirilen hipotezler test edilmiştir. Sonuç ve değerlendirme kısmında ise, analiz sonucu elde edilen bilgiler ile yazın taraması ile elde edilen diğer araştırma sonuçları karşılaştırılarak değerlendirilmeye çalışılmıştır.

\section{Kavramsal Çerçeve}

Bu bölümde hedonik ve faydacı tüketim eğilimi kavramları ile ilgili yazın taraması yapılmaktadır. Ayrıca literatürde yer alan plansız satın alma davranışı ile ilgili bilgilerden yararlanılarak kavram açıklanmaya çalışılmaktadır.

\section{Hedonik ve Faydacı Tüketim Ĕ̆ilimi Kavramı}

Hedone, eski Yunancada haz ve zevk anlamına gelmektedir. Hedonizm ise, hazcllık demektir. Hedonizmin temelinde, 'hayatın en önemli değeri 
haz ve zevk almaktır ve ideal yaşama ancak bu şekilde ulaşılır' fikri vardır (Kök ve Aksel, 2016, s.144). Hedonizm, zevkin peşinde koşma, duyumsal zevklere kendini adama ya da psikolojik olarak zevk arama arzusuyla acıdan kaçma şeklinde güdülenmiş davranış biçimini olarak tanımlanmaktadır (Çelik, 2009, s.47). Hedonizm bakış açısına göre tüketimin amacı ihtiyaçları karşılamak değil, haz duymaktır (Aslım Bilge, 2014, s.18).

Hedonizm, genellikle duygular aracılığıyla memnun olmayı ifade eden bir terimdir. İnsanlar hem olumlu hem de olumsuz çeşitli duygular denemeye çalışırlar. Hedonik tüketim anlayışında, tüketiciler ürün seçerken duygusal istekler bazen faydacı nedenlere daha baskın gelmektedir. İnsanlar sık sık işlevsel faydalar için değil, duygusal hazlar nedeniyle satın alma eğilimindedirler (Coley, 2002, s.33). O'Shaughnessy ve Jackson O'Shaughnessy (2012, s.78-79) duyguların satın alma davranışlarına olan etkisini "duygular davranışı harekete geçirebilir, bir şeyi öne çıarabilir, tercihleri yönlendirebilir ve diğer dürtüleri güçlendirebilir. $\mathrm{Bu}$ yüzden sosyal dürtü, insanın sahip olduğu şeyleri göstermekten duyduğu gurur tarafından pekiştirilir." şeklinde ifade etmektedir.

Hedonizmin seviyesi, kişilere, koşullara ve toplumlara göre farklılık gösterebilir. Hedonik tüketimde temel konu, tatmin ve memnuniyet seviyesinin en üst düzeyde olması gerektiğidir. Ertelenmiş tatmin duygusu yerine, sabırsız ve şu anki tatmin duygusu daha baskın gelmektedir (Koçak, 2013, s.8). Hirschman ve Holbrook (1982, s.92) hedonik tüketimi, tüketimin haz boyutundan tat almak olarak ifade etmektedir. İnsanlar satın aldıkları ürünleri kullanım amacının dışında kendilerini ifade etme tarzı olarak da görmektedirler. Odabaşı'na (2006, s.116) göre, ürünün taşıdığı ve yarattığg imaj, tüketicinin bu duruma verdiği duygusal tepkinin önemini vurgulamaktadır. Birey için ürünün yarattığı öznel semboller, hedonik tüketimde ürünün fonksiyonel özelliklerinin önüne geçmektedir. Tüketicinin ürün ile ilgili hazsal görüşü, aslında o ürünü kullanırken yaşadığı psikolojik tecrübeleri içinde barındırmaktadır. Hedonik tüketim hayal gücüne bağlı olduğu için hedonik tüketici, gerçeğin ne olduğu ile değil nasıl olmasını istediğine göre hareket etmektedir (Kırcl, 2014, s.89; Albayrak, 2017, s.108). 
Tüketicileri satın alma davranışı olarak hedonik/hazcı davranmaya iten sebepleri kısaca şu şekilde belirtmek mümkündür (Arnold ve Reynolds,2003, s. 77-95):

i. Alışveriş yaparken tüketicilerin ihtiyaç ve zaman kavramından uzaklaşıp kendini kaptırarak macera araması,

ii. Çevresindekilerle (sosyal çevre, arkadaş, aile vb.) alışveriş yaparak sosyalleşmek istemesi,

iii. Günlük hayatın stres ve karmaşasından kurtulabilmek için rahatlamak istemesi,

iv. Modayı ve yeni trendleri, piyasaya yeni sürülmüş ürünleri takip edebilmek için fikir sahibi olmak istemesi,

v. Genellikle özel günlerde başkalarını mutlu etmek için hediye vermek istemesi

vi. İndirim dönemlerinde yapılan fırsatları yakalamak istemesi ve ürünleri daha ucuza alarak kazançlı alışveriş yaptıklarını düşünmeleridir (Semiz, 2017, s.15).

Tüketicileri hedonik davranmaya iten sebeplerden bir tanesi de tüketim kültürüdür. Tüketim kültürü, yeni zevklerin benimsenmesini, yeni hazların alınmasını bireyin hakkı ve kendine karşı görevi olarak sunarak hedonik tüketime yönlendirmektedir. Hedonik tüketim, ihtiyaçlardan çok arzulara dayalı göstergelerin öncelikte olduğu bir tüketim kültürünü ortaya çıkarmıştır. Tüketimin anlamı genişlemiş; haz, eğlence ve özgürlük gibi anlamları bünyesinde barındırmaya başlamıştır. Mutluluğun göstergesi daha fazla tüketebilme gücü ile paralel hale gelmiştir (Yanıklar, 2006, s.25). Modern ve post modern tüketim toplumlarında tüketim olgusunun duygusal ve hissi boyutu ön plana çıktığından, insanlar için psikolojik ihtiyaçlarını karşılamak, haz ve zevk almak için bir tatmin aracı olarak işlev görmektedir (Torlak vd., 2007, s.25).

Tüketim davranışında, hedonik tüketimin yan sıra diğer bir boyut olarak faydacı tüketim boyutundan söz edilmektedir. Faydacı boyutta tüketici tüketim faaliyetini bir görev olarak algılamaktadır. Satın alma işini "görevin tamamlanması" olarak değerlendirmekte ve rasyonel bir davranış sergilemektedir (Arnold ve Reynolds, 2003, s.80). Faydacı tüketimde, ihtiyaç duyulan tüketim unsuruna ilişkin olarak alışveriş ziyaretinin değeri, ürünün etkin ve uygun bir biçimde satın alınmasıyla ilişkilendirilmektedir (Babin, vd.1994, s.644). Faydacı tüketim anlayışında 
alışveriş bir "iş" olarak değerlendirilmektedir. İhtiyaç duyulan ya da aranılan ürün bulunduğunda görev tamamlanmakta ve alışveriş sona ermektedir. Faydacı tüketim anlayışında her alışveriş ziyareti bir satın almayla sonlanmak durumunda değildir. Tüketicinin ürünlerle ve fiyatlarla ilgili bilgi edinmek amacıyla yaptığ ziyaretler de faydacı alışveriş davranışı olarak görülmektedir (Bloch ve Richins, 1983, s.390).

Faydacı tüketim anlayışı fonksiyonellik ve duygusal olmayan nitelikle ilgilidir ve faydalı beklentilere odaklanmaktadır (Crowley vd.,1992, s. 239). Tüketici tarafından algılanan kullanışlılık, değer ve bilgisi davranışın faydacı durumu ile ilişkilidir (Ahtola,1985, s.8). Faydacı tüketim, tüm demografik özelliklere eşit oranda çekicidir. Faydacı tüketim yapan kişilerin motivasyonu benzerlik göstermektedir (Hopkinson ve Pujari, 1999, s. 285).

Faydacı tüketim anlayışı, bir nesnenin ya da bir eylemin değerinin onun faydasıyla belirleneceği şeklindeki inanç, olarak tanımlanmaktadır (Kop, 2008, s.112).

Tüketicilerin zorunlu ihtiyaçlarını karşılamak amacıyla gerçekleştirdikleri tüketim, kişilere fayda sağlamasından dolayı faydacı tüketim anlayışı olarak değerlendirilmektedir. Bu açıdan düşünüldügünde bir araba, bir bilgisayar faydacı tüketim kavramına örnek olarak gösterilebilir. Faydacı tüketimin asıl amacı tüketiciye tamamen somut bir fayda sunmasıdır (Şengün ve Karahan, 2013, s.15).

Faydacı tüketimde, tüketim faaliyetinden somut bir fayda sağlanması düşüncesi hâkimdir. Tüketiciler, içten gelen dürtülerin vücutta yarattığ1 psikolojik ya da fizyolojik gerginliklerin en aza indirilmesi veya ortadan kaldırılmasına yardımcı olacak şeyleri satın alarak karşılamaya çalışmaktırlar. Bu anlayışta, tüketiciler rasyonel karar verirler ve ihtiyaçlarını karşılamaya yönelik seçenekler arasından kendileri için en az maliyetle en yüksek faydayı sağlayacak ürünleri değerlendirdikleri ve en uygun olanı tercih ettikleri düşünülmektedir (Altunışık ve Çallı, 2004, s.232).

Hedonik tüketim ile faydacı tüketim anlayışında tüketiciye sağladığı değerler açısından birtakım farklılıklar görülmektedir. Hedonik değerler, satın alma eyleminin sonuncunda elde edilen, psikolojik ve duygusal deneyimlerken; faydacı değer, tüketicinin alışveriş sırasında ve sonrasında rasyonel bir tutumla faydacı olgular aramasıdır. Faydacı değer, başarılı bir alışverişi ve kişinin tatmin olması olarak değerlendirilmekte- 
dir. Hedonik değer ise, tüketicinin sıradanlıktan kaçması ve farklı zevk ve heyecanlar yaşamayı planlamasıdır. Bu çerçevede hedonik değer ve faydacı değer karşılaştırıldığında, hedonik değer öznel, eğlence ve zevke dayalı bir macera sonucunda gerçekleşmektedir (Carpenter vd., 2005, s. $45)$.

\section{Plansız Satın Alma Davranışı}

Plansız satın alma kavramı; tüketicinin, aklında hiçbir satın alma düşüncesi bulunmazken, ani bir kararla meydana getirmiş olduğu satın alma faaliyeti olarak kabul edilmektedir (Altunışık, 2007, s.124). Plansız satın alma davranışı; Clover (1950, s.66) tarafından, "tüketicinin mağazaya girmeden önce herhangi bir plan yapmaksızın mağaza içerisinde satın alma davranışını gerçekleştirmesi" olarak tanımlanmaktadır. Rook (1987, s.191) ise plansız satın alma davranışını, "tüketicinin güçlü ve sürekli olarak bir şey satın alma isteğiyle aniden bir ürünü satın alması" olarak tanımlamaktadır. Piron (1991, s.509), çalışmasında plansız satın alma davranışını "hedonik duygularla veya bir uyarıcıya maruz kalarak gerçekleştirilen plansız satın alma" olarak tanımlamaktadır. Kacen ve Lee (2002, s.163) plansız satın alma davranışını, "hızlı karar verme ve ürüne hemen sahip olma hissiyatıyla meydana gelen plansız satın alma" olarak tanımlamaktadır. Genel anlamda, plansız satın alma davranışı; tüketicinin bir ürünü satın almaya yönelik ani, ısrarlı ve yoğun bir istek duyarak gerçekleştirdiği satın alma davranışı olarak tanımlanabilmektedir (Şenel, 2018, s.38).

Tüketiciler etkisinde kaldıkları iç ve diş faktörler nedeniyle oluşan ilgi düzeylerine göre seçim yaparak kısa süreliğine bilgi depolarlar. Klasik satın alma sürecine kıyasla, plansız satın alma sürecinde tüketiciler alternatiflerin değerlendirme aşamasına çok fazla odaklanmamaktadırlar. Sonuç olarak, kısa süreli hafızalarında depoladıkları bilgiyi çağırarak durumsal faktörlerin yaratmış olduğu deneyimle ürünü satın alırlar (Kotler, 2004, s.201-202). Plansız satın alma karar sürecinde tüketiciler ağırlıklı olarak fiziksel, finansal, sosyal ve psikolojik etmenlere odaklanmaktadırlar. Bu durumun nedeni ise, satın alma arzusunu hissettikleri anda ürünle ilgili yeterli bilgiye sahip olmadan, yeterli bilgiyi topla- 
madan, öncesine ve sonrasina fazla odaklanmadan, akılda olmadan, plansız biçimde satın almalar gerçekleştirmeleridir (Elmaz, 2017, s.15).

Beatty ve Ferrel'e (1998, s.170) göre plansız satın alma davranışının nedeni olarak, tüketicilerin bir ürünü bittiği için değil, bir etkileşim sonucu aldıklarını ve ürünü gördüklerinde hissettikleri duygular sonucunda gerçekleştiğini ortaya koymaktadırlar. Willet ve Kollat (1968, s.326) ise, plansız satın alma kararının önemli bir kısmının mağazadaki uyarıcıların etkisiyle gerçekleştiğini belirtmektedirler. Bayley ve Nancarrow (1998, s.100) ise, plansız satın alma kararının ürünle karşılaşıldığ 1 zaman hissedilen eksiklikten kaynaklandığını vurgulamaktadırlar. Baumeister (2002, s.670) ise yaptı̆̆1 araştırma sonucunda, plansız satın almanın tamamen içgüdüsel ve plansız olduğunu ve mağazaya girmeden önce herhangi bir listeleme, önceden uyarlanmadan, kurgulanmadan ve karşı konulmaz bir istekle gerçekleştiğini ortaya koymuştur.

Stern (1962, s.59-60) tarafindan olansız satın alma davranışı dört kategoriye ayrılmıştır. Bu kategoriler kısaca aşağıda açıklanmaktadır (Baran, 2015, s.105):

i. Tamamen plansız satın alma: Pazara yeni girmiş bir ürünün ya da tüketici tarafından ilk defa görülen bir ürünün deneme maksadıyla yapılan satın alma türüdür.

ii. Hatılatıcı plansız satın alma: Alışveriş listesinde olmayan ancak ürünün mağazada görülmesiyle ihtiyaç olduğu ortaya çıan satın alma türüdür. Ceket satın almaya giden bir tüketicinin kravatı da olmadığını fark etmesi gibi.

iii. Önerici plansız satın alma: Genellikle alış veriş mağazaları tarafından tetiklenen satın alma türüdür. Tüketici ihtiyacı olmayan bir ürünü gördüğünde ihtiyacı olduğunu düşünebilir ya da ürünün rengi, fiyatı gibi özelliklerine kapılarak satın alma yapabilir.

iv. Planlanmış plansız satın alma: Alışveriş niyetiyle mağazaya gidip, alış veril listesinde olmayan, farklı bir ürünü satın alma faaliyetidir. Örneğin, alışverişe pembe bir kazak almak için gidildiğinde, mavi kazak ve uyumlu bir fular almak bu tip satın almaya örnek verilebilir. Bu satın alma tarzında kişi evden çıktığı andaki planından tamamen uzaklaşmış ve başka bir amaca yönelmiştir. 
Hedonik ve Faydacı Tüketim Eğiliminin Plansız Satın Alma Davranışı Üzerindeki Etkisi: Bir Araştırma

\section{Yazın Taraması ve Araştırmanın Hipotezleri}

Özdemir ve Yaman (2007, s.89), Çakmak ve Çakır (2012, s.185) ve Fettahlığlu vd.(2014, s.329) tarafından cinsiyetin hedonik tüketim üzerindeki etkisini belirlemeye yönelik yapılan araştırmalarda kadın tüketicilerin erkeklere oranla daha fazla hedonik satın alma gerçekleştirdiklerini tespit etmişlerdir. Yapılan araştırmalar sonucunda hedonik tüketim anlayışının kişilik özelliklerinden etkilendiği, dışadönük ve yeniliklere açık olan kişilerin daha fazla hedonik tüketim gerçekleştirdiği tespit edilmiştir (Batra ve Ahtola, 1991, s.159; Crowley vd.,1992, s.246; Deniz ve Erciş 2010, s.141; Khan ve Urminsky, 2004, s.360; Matzler vd., 2006, s.430; Voss vd. 2003, s.317). Doğan vd., (2014, s.76) tarafından tüketicilerin demografik özellikleri ile hedonik tüketim anlayışı üzerine yaptıkları araştırma sonucunda, tüketicilerin genç yaşlarda hedonik tüketim alışkanlıklarının yüksek bir düzeyde olduğu ve yaş ilerledikçe artık hazcı tüketim yerine faydacı bir tutum edindikleri bulgusunu elde etmişlerdir. Tüketicilerin medeni durumları ile hedonik tüketim anlayışlarının da ilişkili olduğu, bekâr olan tüketicilerin evli tüketicilere göre daha hedonik tutum sergiledikleri sonucuna ulaşmışlardır.

Faydacı tüketim anlayışının kişilik özelliklerine göre değerlendirildiği araştırmada Deniz ve Erciş (2010, s.141), sorumluluk ve uyumluluk kişilik özelliklerine sahip tüketicilerin faydacı tüketim anlayışını benimsedikleri belirtmişlerdir. Elektronik ortamda alışveriş yapan tüketiciler üzerine yapılan araştırmalarda, hedonik tüketim anlayışından ziyade faydacı tüketim anlayışının benimsendiği sonucuna ulaşılmıştır (Chen vd., 2008, s.3; Keeney, 1999, s.533; To vd., 2007, s.776; Tsao ve Chang, 2010, s.1800).

Mangleburg vd.,(2004, s.111) genç tüketiciler üzerine yaptıkları araştırmada, akranlarıyla alışveriş yapan tüketicilerin daha fazla para harcama ve plansız satın alma gerçekleştirdiklerini ortaya koymuştur. Mihic ve Kursan (2010, s.47-66) tarafindan yapılan araştırmada da benzer bir şekilde 20-29 yaş aralığındaki tüketicilerin plansız satın alma davranışı sergilemeye daha yatkın olduklarını belirtmişlerdir. Willett ve Kollat, (1968, s.327) tarafından yapılan araştırmada, mağaza içi uygulamaların yeni dürtüleri ve gelecekteki ihtiyaçları hatırlatıp tüketicileri plansız satın almaya sevk ettiğini belirtmişlerdir. 
Ünal ve Ceylan (2008, s.281) tarafından yapılan araştırma sonucunda, planlanmamış ve hedonik tüketimde en çok giyim alış verişi yapıldığı, daha sonra gıda ve üçüncü sırada kişisel bakım ürünlerinin satın alındığını belirtmişlerdir.

Allen vd.,(1992, s.493), Mano ve Oliver (1993, s.451) ve Herabadi vd. (2009, s.20), yaptıkları araştırmalar neticesinde plansız satın alma davranışlarında tüketicilerin faydacı tutumdan ziyade hedonik tutum içerisinde oldukları sonucuna ulaşmışlardır. Hirschman ve Holbrook, (1982, s.92)' a göre, planlanmamıss satın almada duygusal istekler, faydacı güdülerden baskın çıkmaktadır. Yu ve Bastin (2010, s.109) yaptıkları araştırmada hedonik alış veriş tutumu ile plansız satın alma niyeti arasında pozitif bir ilişki olduğunu saptamış ve hedonik deneyimlerin daha çok plansız satın almaya neden olabileceği sonucuna ulaşmışlardır. Akturan (2010, s.114) tarafından yapılan araştırmada, tüketicilerin hedonik alışveriş eğilimlerinin plansız satın alma davranışı üzerinde pozitif etkisinin olduğu belirtilmiştir.

Literatürdeki araştırmalar neticesinde hedonik ve faydacı tüketim anlayışı ile tüketicilerin plansız satın alma davranışları arasında ilişki olduğu görülmektedir. Bu araştırmada da örneklem grubunda yer alan tüketiciler açısından benzer ilişkinin varlığı araştırmanın konusunu oluşturmaktadır. Ayrıca, hedonik ve faydacı tüketim anlayışının plansız satın alma davranışı üzerindeki etkisinin tespit edilmesi için aşağıdaki hipotezler geliştirilmiştir.

- Hipotez 1: Hedonik tüketim eğilimi ile plansız satın alma davranışı arasinda pozitif yönlü bir ilişki mevcuttur.

- Hipotez2: Faydacı tüketim eğilimi ile plansız satın alma davranışı arasinda pozitif yönlü bir ilişki mevcuttur.

- Hipotez 3: Hedonik ve faydacı tüketim eğilimi, tüketicilerin plansız satın alma davranışlarını etkilemektedir.

\section{Metodoloji}

\section{Araştırmanın Amacı ve Yöntemi}

Araştırmanın amacı hedonik ve faydacı tüketim eğiliminin, tüketicilerin plansız satın alma davranışlarına etkisini ortaya koymaktır. Araştırma- 
nın amacını gerçekleştirmek için alan araştırması yapılmıştır. Alan araştırmasında anket yönteminden yararlanılmıştır. Tüketicilerin hedonik ve faydacı tüketim eğilimini belirlemek amacıyla Babin vd. (1994) tarafından geliştirilen "Hedonik ve Faydacı Alışveriş Değeri Ölçeği"nden yararlanılmıştır. Tüketicilerin plansız satın alma davranışlarını belirlemek için ise Rook ve Fisher (1995) tarafından hazırlanan ölçek kullanılmıştır. Hedonik tüketim anlayışı, faydacı tüketim anlayışı ve plansız satın alma davranışı orijinal ölçeklerde yer aldığı gibi tek boyut olarak değerlendirmeye tabi tutulmuştur. Araştırmanın amacına yönelik geliştirilen hipotezlerin analizinde korelasyon ve regresyon analizlerinden yararlanılmıştır.

\section{Araştırmanın Örneklemi ve Veri Toplama Aracı}

Araştırmanın evrenini Muğla'nın Marmaris ilçesinde yer alan tüketiciler oluşturmaktadır. Türkiye İstatistik Kurumu 2017 yılı verilerine göre Marmaris ilçe nüfusu 91.871 kişidir (Tüik, 2017). Marmaris ilçe nüfusunun tamamına anket uygulamasının yapılması mümkün değildir. Örneklemin ana kütleyi temsil etme oranını belirlemek amacıyla yapılan hesaplama sonucunda 383 anketin evreni temsil etme yeteneği olduğu belirlenmiştir (www.surveysystem.com). Anket uygulaması esnasında 400 anket formu dağıtılmış ancak 317 anketin analiz edilmeye elverişli olduğu tespit edilmiştir.

Anket formunun oluşturulmasında geçerliliği ve güvenilirliği test edilmiş ölçeklerden yararlanılmıştır. Anket formu üç bölümden oluşmaktadır. İlk bölümünde "Hedonik ve Faydacı Tüketim Eğilimi"ni ölçmeye yönelik sorular yer almaktadır. İkinci bölümde "Plansız Satın Alma Davranışı" ölçeği ifadeleri, son bölümde ise yaş, eğitim durumu, medeni durum vb. sorulardan oluşan demografik bilgiler yer almaktadır. Anket formunda yer alan ölçeklere ilişkin bilgiler şu şekildedir:

Hedonik ve Faydacı Tüketim Eğilimi: Tüketicilerin hedonik ve faydacı tüketim eğilimlerini belirlemek amacıyla Babin vd. (1994) tarafından geliştirilen ve Akgül (2014) tarafından Türkçe' ye çevrilip güvenilirliği ve geçerliliği test edilen ölçek kullanılmıştır. Hedonik tüketimi ölçen 10 ifade, faydacı tüketim eğilimini ölçen 5 ifade olmak üzere toplam 15 ifa- 
deden oluşmaktadır. Anket formunda 5'li likert ölçeği kullanılmıştır ve 1-Kesinlikle Katılmıyorum, 5-Kesinlikle Katılıyorum' u ifade etmektedir.

Plansız Satın Alma Davranışı: Tüketicilerin alış veriş yaparken plansız satın alma davranışına yönelik görüşlerini almak amacıyla Rook ve Fisher (1995) tarafından hazırlanan ölçek kullanılmıştır. Torlak ve Tiltay (2010) tarafından Türkçe' ye çevrilen ölçeğin geçerlilik ve güvenilirliği test edilmiştir. Ölçek 9 ifadeden oluşmaktadır ve 5'li likert skalası ile tüketicilerin görüşleri tespit edilmiştir. Cevaplarda 1-Kesinlikle Katılmıyorum ile 5-Kesinlikle Katılıyorum arasındaki skaladan oluşmaktadır.

\section{Araştırma Bulgularının Değerlendirilmesi}

Anket uygulaması sonucunda elde edilen veriler IBM SPSS 21.0 istatistik paket programı kullanılarak analiz edilmiştir. Araştırma amacına yönelik oluşturulan hipotezler \%95 güven aralığında değerlendirilmiştir.

\section{Demografik Veriler}

Araştırmaya katılan tüketicilerin cinsiyet, yaş, medeni durum, eğitim düzeyi vb. demografik bilgileri aşağıda Tablo 1' de gösterilmektedir.

Tablo 1: Araştırmaya Katılanların Tüketicilerin Demografik Bilgileri

\begin{tabular}{|c|c|c|c|c|c|}
\hline Cinsiyet & Kişi & Yüzde (\%) & Medeni Durum & Kişi & Yüzde (\%) \\
\hline Kadın & 181 & 57,1 & Evli & 216 & 68,1 \\
\hline Erkek & 136 & 42,9 & Bekâr & 101 & 31,9 \\
\hline Yaş & Kişi & Yüzde (\%) & Ĕgitim Düzeyi & Kişi & Yüzde (\%) \\
\hline 20 Yaş ve Altı & 41 & 12,9 & Lise & 64 & 20,2 \\
\hline 21- 29 Yaş Arası & 18 & 5,7 & Önlisans & 82 & 25,9 \\
\hline 30 - 39 Yaş Arası & 140 & 44,2 & Lisans & 155 & 48,9 \\
\hline 40 - 49 Yaş Arası & 81 & 25,6 & Lisansüstü & 16 & 5,0 \\
\hline 50 - 59 Yaş Arası & 31 & 9,8 & & & \\
\hline 60 Yaş ve Üzeri & 6 & 1,9 & & & \\
\hline Görev & Kişi & Yüzde (\%) & Gelir Durumu & Kişi & Yüzde (\%) \\
\hline Memur & 135 & 42,6 & 1000 TL ve altı & 40 & 12,6 \\
\hline Esnaf/Tüccar & 37 & 11,7 & 1001-1999 TL & 18 & 5,7 \\
\hline Serbest Meslek & 46 & 14,5 & $2000-2999$ TL & 44 & 13,9 \\
\hline İşçi & 31 & 9,8 & 3000-3999 TL & 69 & 21,8 \\
\hline Öğrenci & 54 & 17,0 & $4000-4999 \mathrm{TL}$ & 71 & 22,4 \\
\hline Emekli & 14 & 4,4 & 5000 TL üzeri & 75 & 23,7 \\
\hline TOPLAM & 317 & 100,0 & TOPLAM & 317 & 100,0 \\
\hline
\end{tabular}


Araştırmaya katılan tüketicilerin yaklaşık \%57'si kadınlardan, \%43'ü erkeklerden oluşmaktadır. Katılımcıların büyük bir kısmı 30-39 yaş aralığında yer almaktadır. Tüketicilerin görevleri incelendiğinde büyük bir kısmı memurlardan oluşmaktadır. Medeni durumları incelendiğinde büyük bir kısmı evlidirler. Eğitim düzeyleri incelendiğinde büyük bir kısmı lisans mezunudur. Tüketicilerin gelir düzeylerine bakıldığında büyük bir kısmı 3000 TL üzeri aylık gelire sahiptirler.

\section{Güvenilirlik Analizi ve Tanımlayıcı İstatistikler}

Tüketicilerin hedonik ve faydacı tüketim anlayışı ile plansız satın alma davranışları arasındaki ilişkiyi tespit etmek amacıyla oluşturulan ölçeğin toplam güvenilirliği (Cronbach's Alpha) \%91,2 çıkmıştır. Anket formunda kullanılan ölçekler genel olarak oldukça yüksek güvenilirliğe sahiptir. Ölçekler ile ilgili betimsel istatistik verileri aşağıdaki tabloda yer almaktadir.

Tablo 2: Hedonik-Faydacı Tüketim ve Plansız Satın Alma Davranışı Ölçekleri Betimsel İstatistiği

\begin{tabular}{llllll}
\hline Ölçekler & N & Min. & Max. & Ort. & S.S. \\
\hline Hedonik Tüketim Ölçeği & 317 & 1,00 & 5,00 & 3,18 & 0,95 \\
Faydacı Tüketim Ölçeği & 317 & 1,40 & 5,00 & 3,20 & 0,77 \\
Plansız Satın Alma Davranışı Ölçeği & 317 & 1,00 & 5,00 & 2,48 & 0,89 \\
\hline
\end{tabular}

Tablo 2' de ki tanımlayıcı istatistikî bilgilere göre, araştırmaya katılan tüketicilerin hedonik tüketim ile ilgili görüşlerinin ortalaması 3,18 çlkmiştır. 5'li likert ölçeğinde ortalama değerin 3 olduğu düşünüldüğünde, katılımcıların hedonik/hazcı tüketim eğilimlerinin ortalamanın biraz üzerinde olduğu görülmektedir. Araştırmaya katılan tüketiciler, alışverişlerinde hazcl, heyecan verici ve duyguların ön planda olduğu bir tüketim tarzını orta düzeyde benimsemektedirler.

Katılımcıların faydacı tüketim anlayışına yönelik görüşlerinin ortalaması ise 3,20'dir. Faydacı tüketim eğilimi de ortalama değerin biraz üzerine çıkmıştır. Araştırmaya katılan tüketicilerin alışverişlerinde faydayı ön planda tutmaları ve rasyonel davranma düzeyleri ortanın biraz üzerindedir. 
Araştırmaya katılan tüketicilerin plansız satın alma davranışına yönelik ifadelere ortalama katılım düzeyi 2,48'dir. Ortalamanın altında plansız satın alma eğilimin oldukları görülmektedir. Örneklem içerisinde yer alan müşterilerin alış verişlerinde daha çok planlı hareket ettikleri sonucu ortaya çıkmaktadır.

\section{Araştırma Hipotezlerinin Test Edilmesi}

Araştırmanın amacına yönelik belirlenmiş ola hipotezlerin test edilmesi amaciyla korelasyon ve regresyon analizi uygulanmıştır. Analiz sonucunda elde edilen bilgiler ve hipotezlere ilişkin sonuçlar aşağıda tablolar ile belirtilmektedir.

Hipotez 1: Hedonik tüketim eğilimi ile plansız satın alma davranışı arasında pozitif yönlü bir ilişki mevcuttur.

Araştırmaya katılan tüketicilerin hedonik tüketim eğilimi ile plansız satın alma davranışı arasında ki ilişkinin varlığını tespit etmek amacıyla korelasyon analizi uygulanmıştır. Korelasyon analizi sonucunda ortaya çıkan ilişki düzeyi aşağıdaki tabloda belirtilmektedir.

Tablo 3: Hipotez 1'e Yönelik Korelasyon Analizi Tablosu

\begin{tabular}{llll}
\hline \multicolumn{2}{l}{ Korelâsyon Analizi } & & Plansız Satın Alma Davranışı \\
\hline Pearson & Hedonik & KorelâsyonKatsayısı &, $\mathbf{6 4 7 ^ { * * }}$ \\
Korelâsyon & Tüketim & Sig.(2-kuyruklu) &, 000 \\
Analizi & Anlayışı & Kişi & 317 \\
& & &
\end{tabular}

**Korelâsyon 0.01 düzeyinde anlamlıdır.

Plansız satın alma davranışı ile hedonik tüketim anlayışı arasındaki ilişkinin incelendiği hipotez 1 sonuçlarına göre, aralarında pozitif yönlü ve \%64,7 düzeyinde bir ilişkinin olduğu tespit edilmiştir. Tablo 3'den elde edilen bilgiler ışığında Hipotez 1 Kabul edilmektedir. Analiz sonuçlarını değerlendirmek gerekirse, plansız yapılan alışverişlerin büyük bir bölümü hedonik/ hazcı tüketim eğiliminden kaynaklanmaktadır. Tüketi- 
Hedonik ve Faydacı Tüketim Eğiliminin Plansız Satın Alma Davranışı Üzerindeki Etkisi: Bir Araştırma

ciler duygularına hitap eden, hazcı ve heyecan verici bir ürün ile karşılaştıklarında plansız satın alma gerçekleştirme eğilimindedirler.

Hipotez 2: Faydacı tüketim eğilimi ile plansız satın alma davranışı arasında pozitif yönlü bir ilişki mevcuttur.

Tüketicilerin faydacı tüketim eğilimi ile plansız satın alma davranışları arasındaki ilişkiyi ölçen hipotez 2 sonuçları tablo 4'te gösterilmektedir.

Tablo 4: Hipotez 2' ye Yönelik Korelasyon Analizi Tablosu

\begin{tabular}{llll}
\hline \multicolumn{2}{l}{ Korelâsyon Analizi } & & Plansız Satın Alma Davranışı \\
\hline Pearson & Faydacı & KorelâsyonKatsayısı & $\mathbf{, 1 2 1}^{*}$ \\
Korelâsyon & Tüketim & Sig.(2-kuyruklu) &, 031 \\
Analizi & Anlayışı & Kişi & 317
\end{tabular}

**Korelâsyon 0.01 düzeyinde anlamlıdır.

Araştırmaya katılan tüketicilerin faydacı tüketim eğiliminde olmaları ile plansız satın alma davranışları arasındaki ilişki Tablo 4'de gösterilmektedir. Tablo verilerine göre plansız satın alma davranışı ile faydacı tüketim eğilimi arasında pozitif yönlü ve anlamlı \%12,1 düzeyinde bir ilişki tespit edilmiştir. Analiz sonuçlarına göre Hipotez 2 Kabul edilmektedir. Analiz sonuçlar değerlendirildiğinde, faydacı ve rasyonel tüketim anlayışını benimseyen tüketiciler düşük düzeyde plansız satın alma davranışı gerçekleştirmektedirler. Rasyonel davranan tüketicilerin daha çok planlı alış veriş yaptıkları şeklinde değerlendirme yapmak mümkündür.

Hipotez 3: Hedonik ve faydacı tüketim eğilimi, tüketicilerin plansız satın alma davranıslarnı etkilemektedir.

Hedonik ve faydacı tüketim eğiliminin, plansız satın alma davranışı üzerindeki etkisini belirlemek amacıyla çoklu regresyon analizi gerçekleştirilmiştir. Analiz sonuçlarına Tablo 5' te yer verilmektedir.

Tablo 5'de yer alan regresyon modeline göre hedonik ve faydacı tüketim eğiliminin plansız satın alma davranışı üzerinde $\% 45(p=, 000)$ oranında etkisi bulunmaktadır. Regresyon modelinde otokorelasyon olup olmadığını gösteren Durbin-Watson değeri 1,569’ dur. Durbin-Watson 
değerinin 1,5-2,5 aralığında olması regresyon modelinde otokorelasyonun olmadığının göstergesidir.

Tablo 5: Hipotez 3'ye Yönelik Çoklu Regresyon Analizi

Bağımlı Değişken: Plansız Satın Alma Davranışı

\begin{tabular}{lllllll}
$\begin{array}{l}\text { Bağımsız Değiş- } \\
\text { kenler }\end{array}$ & $\mathbf{R}^{2}$ & $\mathbf{F}$ & $\boldsymbol{\beta}$ & $\mathbf{t}$ & $\mathbf{p}$ & $\begin{array}{l}\text { Durbin } \\
\text { Watson }\end{array}$ \\
\hline $\begin{array}{l}\text { Hedonik Tüketim } \\
\text { Faydacı Tüketim }\end{array}$ & \multirow{2}{*}{450} & $128,595^{* *}$ &, 621 & 15,772 &, $\mathbf{0 0 0}$ & \\
\hline
\end{tabular}

${ }^{*} \mathrm{p}<0,05^{* *} \mathrm{p}<0,01$ düzeyinde anlamlıdır.

Regresyon modelinde beta değerleri incelendiğinde Hedonik tüketimin $\beta$ katsayısı 0,621, faydacı tüketim eğiliminin ise $\beta$ katsayısı $0,21^{\prime}$ dir. Plansız satın alma davranışı üzerinde hedonik tüketim eğiliminin \%62 oranında, faydacı tüketimin eğiliminin ise \%21 oranında etkisi vardır. Regresyon modeli genel olarak değerlendirildiğinde; plansız satın alma davranışında bir birimlik artışın $0,45^{\prime} \mathrm{i}$, hedonik ve faydacı tüketim eğiliminden etkilenmektedir. Tablo $5^{\prime}$ de sonuçlarına yer verilen regresyon modeline göre Hipotez 3 Kabul edilmiştir.

\section{Değerlendirme Ve Sonuç}

Tüketicilerin plansız/ani satın alma davranışlarında hedonik ve faydacı tüketim eğiliminin ne kadar etkisinin olduğunu araştıran bu çalışmada alan araştırması gerçekleştirilmiş ve istatistiksel olarak anlamlı sonuçlar elde edilmiştir. Araştırmaya katılan tüketicilerin ortalama değerin biraz üzerinde hedonik/hazcı tüketim eğilimde oldukları görülmektedir. Alı̧̧verişte rasyonel davranan faydacı tüketim eğiliminde olan tüketicilerin oranı da ortalamanın üzerindedir. Araştırmaya katılan tüketicilere plansız/ani satın alma davranışına yönelik sorular yöneltildiğinde, ortalamanın altında plansız satın alma davranışı sergileyen tüketici olduğu anlaşılmaktadır.

Hedonik tüketim anlayışı ile plansız satın alma davranışı arasındaki ilişki incelendiğinde pozitif yönlü, anlamlı ve güçlü bir ilişkinin olduğu ortaya çıkmaktadır. Duygulara hitap eden, heyecan verici ve haz duygusunu arttıran ürünler olduğunda, tüketicilerin ani ve plansız satın alma 
davranışı sergiledikleri görülmektedir. Ünal ve Ceylan (2008, s. 281) tarafından yapılan araştırmada da benzer sonuçlar ortaya çıkmış, özellikle giyim, gıda ve kişisel bakım ürünlerinde hedonik tüketim eğiliminin plansız satın almaya sevk ettiği belirtilmiştir. Yu ve Bastin (2010, s.109) ve Akturan (2010, s.114) tarafından yapılan araştırmalarda da hedonik tüketimin plansız satın alma davranışı ile pozitif yönlü ve ilişkili olduğu sonucuna ulaşılmıştır.

Faydacı tüketim eğilimi ile plansız satın alma davranışı arsındaki ilişkinin incelendiği korelasyon analizi sonucunda anlamlı ve pozitif yönlü bir ilişkinin olduğu ancak bu ilişkinin düzeyinin düşük olduğu tespit edilmiştir. Rasyonel davranan, faydacı tüketim eğiliminde olan tüketicilerde, alışveriş esnasında kendileri için faydalı olduklarını düşündükleri ürünleri satın almada ani kararlar verebilmektedirler.

Plansız satın alma davranışı üzerinde hedonik ve faydacı tüketim eğiliminin etkisinin test edildiği çoklu regresyon analizi neticesinde \%45 düzeyinde, oldukça yüksek bir etkinin olduğu tespit edilmiştir. Hedonik tüketimin etkisi \%62 düzeyinde iken, faydacı tüketim eğiliminin etkisi \%21 düzeyinde kalmıştır. Allen vd.,(1992, s.493), Mano ve Oliver (1993, s.451), Herabadi vd. (2009, s.20), Hirschman ve Holbrook, (1982, s.92) tarafından yapılan araştırmalarda da benzer sonuçlar elde edilmiş, faydacı tüketim eğiliminden ziyade hedonik tüketim anlayışının planlanmamış satın alma davranışı üzerinde daha etkili olduğu belirtilmiştir.

Sonuç olarak, tüketicilerin alışveriş planlarında olmayan ve ani olarak verdikleri satın alma kararlarında hedonik ve faydacı tüketim eğiliminin önemli derecede etkisi olduğu görülmektedir. Hedonik tüketimin, müşterileri faydacı tüketimden daha çok plansız satın alma davranışına yönelttiği görülmektedir. Alışveriş mağazalarının bu sonuçları dikkate alarak, müşterilerinin haz duygularını arttıracak, onlara heyecan verecek ve duygularına hitap eden ürünleri müşterilere daha kolay satabileceklerini bilmeleri, mağaza tasarımını buna göre yapmaları öneri olarak sunulabilir. Sonraki çalışmalara tavsiye olarak; plansız satın alma davranışını etkileyebilecek diğer unsurların neler olduğu konusunda araştırmaların yapılmasının hem akademik dünyaya hem de iş dünyasına katkısı olacağı düşünülmektedir. 


\title{
EXTENDED ABSTRACT \\ The Effect of Hedonic and Utilitarian Consumption Tendency on Impulse Buying Behavior: A Research
}

\author{
Zehra Türk \\ Muğla Sitkı Koçman University
}

Consumption culture, by presenting the adoption new pleasures and the reception new tastes as person's duty and his right against himself, leads him to hedonic consumption. Hedonic consumption has revealed a consumption culture which prioritizes indicators based on wishes rather than needs. The meaning of consumption has expanded; it has began to contain meanings such as pleasure, fun and freedom within itself. The indicator of happiness has come to parallel situation by the power of being able to consume more.

In consumption behavior, besides hedonic consumption, as an another dimension is mentioned the utilitarian consumption dimension. At the utilitarian dimension, consumer perceives the consumption activity as a mission. He evaluates the work of buying as "mission completing" and he displays a rational behavior. In understanding of utilitarian consumption, every shopping visit is not in the position of ending with a buying. Visits of consumers' to get information about products and prices are also seen as utilitarian shopping behavior.

It has seen that there are a number of differences from the point of the values provided to the consumer in the understanding of utilitarian consumption with hedonic consumption. While hedonic values are the psychological and emotional experiences which obtained at the end of the act of buying; the utilitarian value is that the consumer is looking for utilitarian facts with a rational manner during and after shopping. Utilitarian value is evaluated as a successful shopping and satisfaction of the person. The hedonic value is that the consumer tries to escape from ordinariness and plans to live the different pleasures and excitements.

The concept of unplanned buying is accepted as a buying activity that he has created with a sudden decision, when there isn't any buying ideas 
in consumer's mind. Unplanned buying behavior can be defined as the buying behavior of the consumer by having a sudden, persistent and intense desire to buy a product. The consumers store the information for a short time by choosing according to the levels of their attention, which happens due to the internal and external factors, that they are impressed. In comparison with classical buying process, in unplanned buying process; the consumers don't focus on the phase of evaluation of alternatives too much. As a result, by calling the information, which they store in their short term memory, they buy the product with the experience, which is created by situational factors.

In unplanned buying decision process, consumers focus on predominantly the physical, financial, social and psychological elements. The reason for this situation is, that at that moment they feel the desire to buy, they make real the buys unplanningly; without having and collecting enough information about the product, without focusing much on its before and after, without being in mind.

The aim of the study is to reveal the effect of hedonic and utilitarian consumption tendency on consumers' unplanned buying behavior. A field study was carried out to realize the purpose of the research. Survey method was used in the field research. The understanding of hedonic consumption, the concept of utilitarian consumption and unplanned buying behavior were subjected to evaluate as one dimension like is located in the original scales. In the analysis of hypotheses, that was developed for the aim of the study, it has been benefited from correlation and regression analyzes.

The population of the study is composed of consumers, who are located in the county Marmaris of Muğla. During the survey application, 400 questionnaires were distributed, but 317 questionnaires were found to be suitable for analysis.

Correlation and regression analysis were applied to test the hypotheses determined for the purpose of the study. The informations that were obtained in the results of the analysis and the results of the hypotheses are shown in the tables below. 
Hypothesis 1: There is positively relationship between hedonic consumption tendency and unplanned buying behavior

According to the results of Hypothesis 1, that was evaluated the relationship between unplanned buying behavior and the understanding of hedonic consumption, it has been determined that there is a positively and in the level of 64.7 relationship between them. Hypothesis 1 is accepted in the light of the information, that is obtained from Table 3. If the results of the analysis need to evaluate, most of the unplanned buys are due to hedonic / hedonic consumption tendency. Consumers tend to perform unplanned buys when they encounter a hedonistic and exciting product that addresses their emotions.

Hypothesis 2: There is positively relationship between utilitarian consumption tendency and unplanned buying behavior.

A positively and a significantly in the level of \% 12.1 relationship was determined between unplanned buying behavior and utilitarian consumption tendency. According to the results of the analysis, Hypothesis 2 is accepted. When the results of the analysis are evaluated, the consumers, who adopt the utilitarian and rational consumption understanding, realize a low level of unplanned purchasing behavior. It is possible to make evaluation that the consumers, who behave rational,make more planned shopping.

Hypothesis 3: The tendency of hedonic and utilitarian consumption affects the unplanned buying behavior of consumers.

According to the multiple regression model, hedonic and utilitarian consumption tendency has in proportion $45 \%$ effect on unplanned buying behavior. Hypothesis 3 is accepted according to regression model. As a result of the study, it is come to existence that there is a positive, meaningful and strong relationship between hedonic consumption approach and unplanned buying behavior. It is seen that consumers exhibit sudden and unplanned buying behavior when the products are addressing their emotions, exciting and giving them a kick. As the result of correlation analysis, that has been analyzed the relationship between the utilita- 
rian consumption tendency and unplanned buying behavior, it was found that there was a significantly and positively relationship,but it has determined that the level of this relationship was low. Consumers too, who act rationally and have the utilitarian consumption tendency, can make sudden decisions in buying the products, that they think are useful for them, during shopping. In the consequence of multiple regression analysis, which tested the effect of hedonic and utilitarian consumption tendency on unplanned buying behavior, it has been determined that there is a very high effect at $45 \%$. While the effect of hedonic consumption was $62 \%$, the effect of utilitarian consumption trend remained at $21 \%$.

\section{Kaynakça/References}

Ahtola, O. T. (1985). Hedonic and utilitarian aspects of consumer behavior: An attitudinal perspective. Association for Consumer Research, $12,7-10$.

Akgül, D. (2014). Hedonik (Hazcı) tüketimin özel günlerdeki alışveriş kültürü üzerindeki etkisi ve ülkelerarası karşılaştırmalı bir araştırma. (Yayımlanmamış Doktora Tezi), Erciyes Üniversitesi, Kayseri.

Akturan, U. (2010). Hedonik tüketim eğiliminin plansız satın alma eğilimi üzerindeki etkisinin belirlenmesi. Öneri Dergisi, 9(33), 109-116.

Albayrak, E. S. (2017). Hedonik ve faydacı tüketim bağlamında internet üzerinden alı̧̧veriş alı̧̧kanlıkları: Bir uygulama örneği. (Yayımlanmamış Doktora Tezi), Selçuk Üniversitesi, Konya.

Allen, C. T., Machleit, K. A., ve Kleine, S. S. (1992). A comparison of attitudes and emotions as predictors of behavior at diverse levels of behavioral experience. Journal of Consumer Research, 18(4), 493504 .

Altunsşık, R. (2007). Yeni tüketicinin tüketime yansıyan farklllıkları, yeni müşteri. İstanbul: Hayat Yayıncılık.

Altunışık, R. ve Çallı, L. (2004). Plansız alışveriş ve hazcı tüketim davranışları üzerine bir araştırma: Satın alma karar sürecinde bilgi kullanımı. 3. Ulusal Bilgi, Ekonomi ve Yönetim Kongresi, Eskişehir, 231-239. 
Arnold, M. J., ve Reynolds, K. E. (2003). Hedonic shopping motivations. Journal of Retailing, 79(2), 77-95.

Aslım Bilge, H. (2014). Hedonik tüketimde tüketici motivasyonlarn: bir model önerisi. (Yayımlanmamış Doktora Tezi), Ege Üniversitesi, İzmir.

Babin, B. J., Darden, W. R., ve Griffin, M. (1994). Work and/or fun: Measuring hedonic and utilitarian shopping value. Journal of Consumer Research, 20(4), 644-656.

Baran, Z.(2015). Satın alma noktası reklam uygulamalarmın plansiz satın alma davranışındaki rolü: Ikea örneği. (Yayımlanmamış Yüksek Lisans Tezi), İzmir: Ege Üniversitesi.

Batra, R., ve Ahtola, O. T. (1991). Measuring the hedonic and utilitarian sources of consumer attitudes. Marketing Letters, 2(2), 159-170.

Baumeister, R. F. (2002). Yielding to temptation: Self-control failure, impulsive purchasing, and consumer behaviour. Journal of Consumer Research, 28(4), 670-676.

Bayley, G., ve Nancarrow, C. (1998). Impulse purchasing: A qualitative exploration of the phenomenon. Qualitative Market Research: An International Journal, 1(2), 99-114.

Beatty, S. E., ve Ferrell, M. E. (1998). Impulse buying: modeling its precursors. Journal of Retailing, 74(2), 169-191.

Bloch, P. H., ve Richins, M. L. (1983). Shopping without purchase: An investigation of consumer browsing behaviour. Association for Consumer Research, 10, 389-393.

Çakır, M., ve Çakmak, A. Ç. (2012). 12-18 yaş arası gençlerin hedonik tüketim davranışlarının incelenmesi: Kocaeli şehir merkezinde bir araştırma. Tarih, Kültür ve Sanat Araştırmaları Dergisi, 1(4), 171189.

Carpenter, J. M., Moore, M., ve Fairhurst, A. E. (2005). Consumer shopping value for retail brands. Journal of Fashion Marketing and Management: An International Journal, 9(1), 43-53.

Çelik, S. (2009), Hazsal ve faydacı tüketim. İstanbul: Derin Yayınları.

Chen, M., Lee, H., Lin, S. ve Tsai, K. (2008). Creating value for online shoppers. International Conference on Business and Information, Seoul Korea, 7-9 July 2008, 1-14.

Clover, V. T. (1950). "Relative Importance of Impulse-Buying in Retail Stores". Journal of Marketing, 15(1), 66-70. 
Coley, A. L. (2002). Affective and cognitive processes involved in impulse buying. (Unpublished Master Thesis), The University of Georgia, Athens.

Crowley, A. E., Spangenberg, E. R., ve Hughes, K. R. (1992). Measuring the hedonic and utilitarian dimensions of attitudes toward product categories. Marketing Letters, 3(3), 239-249.

Deniz, A., ve Erciş, A. (2010). Kişilik özellikleri, hedonik ve rasyonel fayda, marka duygusu ve marka bağlılığı arasındaki ilişkilerin belirlenmesine yönelik bir araştırma. Atatürk Üniversitesi İktisadi ve İdari Bilimler Dergisi, 24(2), 141-165.

Doğan, H. G., Gürler, A. Z., ve Ağcadağ, D. (2014). Hedonik tüketim alışkanlıkları üzerine etkili faktörlerin değerlendirilmesi (Tokat İli Örneği). Uluslararası Sosyal Araştırmalar Dergisi, 7(30), 69-77.

Elmaz, N.B., (2017). Tüketicilerin plansız satın alma kararları üzerinde rolü olan etkenlerin belirlenmesi: Bir alan araştırması. (Yayımlanmamış Yüksek Lisans Tezi), İstanbul Üniversitesi, İstabul.

Fettahlıoğlu, H. S., Yıldız, A. ve Birin, C. (2014). Hedonik tüketim davranışları: Kahramanmaraş Sütçü İmam üniversitesi ve Adıyaman üniversitesi öğrencilerinin hedonik alışveriş davranışlarında demografik faktörlerin etkisinin karşılaştırmalı olarak analizi. The Journal of Academic Social Science Studies, 27, 307-331.

Herabadi, A. G., Verplanken, B. ve Van Knippenberg, A. (2009). Consumption experience of impulse buying in Indonesia: Emotional arousal and hedonistic considerations. Asian Journal of Social Psychology, 12(1), 20-31.

Hirschman, E. C. ve Holbrook, M. B. (1982). Hedonic consumption: Emerging concepts, methods and propositions. The Journal of Marketing, 46 (3), 92-101.

Hopkinson, G. C. ve Pujari, D. (1999). A factor analytic study of the sources of meaning in hedonic consumption. European Journal of Marketing, 33(3/4), 273-294.

Kacen, J. J. ve Lee, J. A. (2002). The influence of culture on consumer impulsive buying behavior. Journal of Consumer Psychology, 12(2), 163-176.

Keeney, R. L. (1999). The value of internet commerce to the customer. Management Science, 45(4), 533-542. 
Khan, U. ve Urminsky, O. (2004). Navigating between virtues and vices: Moderators of decisions involving hedonic versus utilitarian choices. Association for Consumer Research, 31, 358-361.

Kırcı, H. (2014). Hedonik tüketim davranışları ve toplumsal etkileri. paradoks ekonomi. Sosyoloji ve Politika Dergisi, 10(1), 80-100.

Koçak, A. (2013). The effect of hedonic shopping values and price in different age, gender and income groups for mobile phone. (Unpublished Master Thesis), Bahçeşehir University, İstanbul.

Kök, S.B.ve Aksel, İ. (2016). İş hayatında nicel başarı tanımlamasına bir karşı duruş: Erdem ahlâkı yaklaşımı, (Ed. S. Sarı, A. H. Gencer, İ. Sözen), International Conference On Eurasian Economies 2016, Kaposvár - Hungary 29-31 August 2016, Beykent University Publications No: 115, 140-149.

Kop, A. E. (2008). Satın alma davranışında hedonik ve faydacı tüketimin ölçülmesi ile ilgili bir uygulama. (Yayımlanmamış Yüksek Lisans Tezi), Marmara Üniversitesi, İstanbul.

Kotler P., (2004). Marketing management, Eleventh Edition, USA: Prentice Hall.

Mangleburg, T. F., Doney, P. M., ve Bristol, T. (2004). Shopping with friends and teens' susceptibility to peer influence. Journal of Retailing, 80(2), 101-116.

Mano, H., ve Oliver, R. L. (1993). Assessing the dimensionality and structure of the consumption experience: Evaluation, feeling, and satisfaction. Journal of Consumer Research, 20(3), 451-466.

Matzler, K., Bidmon, S., ve Grabner-Kräuter, S. (2006). Individual determinants of brand affect: The role of the personality traits of extraversion and openness to experience. Journal of Product ve Brand Management, 15(7), 427-434.

O'Shaughnessy, J., ve Jackson O'Shaughnessy, N. (2002). Marketing, the consumer society and hedonism. European Journal of Marketing, 36(5-6), 524-547.

Odabaş1, Y. (2006). Tüketim kültürü: Yetinen toplumdan tüketen topluma. İstanbul: Sistem Yayıncılık.

Özdemir, Ş., ve Yaman, F. (2007). Hedonik alışverişin cinsiyete göre farklılaşması üzerine bir araştırma. Eskişehir Osmangazi Üniversitesi İ̈BF Dergisi, 2(2), 81-91. 
Hedonik ve Faydacı Tüketim Eğiliminin Plansız Satın Alma Davranışı Üzerindeki Etkisi: Bir Araştırma

Piron, F. (1991). Defining impulse purchasing. Association for Consumer Research, 18, 509-514.

Rook, D. W. (1987). The buying impulse. Journal of Consumer Research, 14(2), 189-199.

Rook, D. W., ve Fisher, R. J. (1995). Normative influences on impulsive buying behaviour. Journal of Consumer Research, 22(3), 305-313.

Semiz, B. B. (2017). A ve B tipi kişilik özelliklerine göre tüketicilerin plansız, kompülsif ve hedonik satın alma davranışlarının araştırılması. Pazarlama İçgörüsü Üzerine Çalışmalar, 1(1/2), 13-22.

Şenel, M. (2018). Farklı kıtlı mesajlarının plansız satın alma niyeti üzerindeki etkisi ve fomo (firsatları kaçırma korkusu)'nun aracı rolü. (Yayımlanmamış Yüksek Lisans Tezi), Karabük Üniversitesi, Karabük.

Şengün, H. İ. ve Karahan, M. (2013). Hedonik (Hazcı) tüketim alışkanlıkları ve tüketicileri bu tür alışkanlıklara motive eden nedenler. Dicle Üniversitesi İktisadi ve İdari Bilimler Fakültesi Dergisi, 2(4), 1326.

Stern, h. (1962). The significance of impulse buying today. The Journal of Marketing, 26(2), 59-62.

The Survey System, "Sample Size Calculator", https://www.surveysystem.com/sscalc.htm, Erişim Tarihi: 20.20.2018.

To, P. L., Liao, C. ve Lin, T. H. (2007). Shopping motivations on internet: a study based on utilitarian and hedonic value. Technovation, 27(12), 774-787.

Torlak, Ö. ve Tiltay, M. A. (2010). Anlık satın alma ölçeklerinin Türk tüketicisi için uyarlanmasına yönelik bir deneme. 15. Ulusal Pazarlama Kongresi Bildiriler Kitabı, 406-423.

Torlak, Ö., Altunışık, R., ve Özdemir, Ş. (2007). Postmodern dünyada tüketimi yeniden anlamlandıracak yeni müşteri. İstanbul: Hayat Yayınc-lik.

Tsao, W. C., ve Chang, H. R. (2010). Exploring the impact of personality traits on online shopping behavior. African Journal of Business Management, 4(9), 1800-1812.

Tüik, (2017). Türkiye İstatistik Kurumu, Adrese Dayalı Nüfus Kayıt İstatistikleri,http://tuik.gov.tr/PreIstatistikTablo.do?istab_id=2305. 
Ünal, S. ve Ceylan, C. (2008). Tüketicileri hedonik alışverişe yönelten nedenler: İstanbul ve Erzurum illerinde karşılaştırmalı bir araştırma. Atatürk Üniversitesi İktisadi ve İdari Bilimler Dergisi, 22(2), 265-283.

Voss, K. E., Spangenberg, E. R. ve Grohmann, B. (2003). Measuring the hedonic and utilitarian dimensions of consumer attitude. Journal of Marketing Research, 40(3), 310-320.

Willett, R. P., ve Kollat, D. T. (1968). Customer impulse purchasing behavior: Some research notes and a reply. Journal of Marketing Research, 5(3), 326-330.

Yanıklar, C. (2010). Tüketim kültürü, kapitalizm ve insan ihtiyaçları arasindaki ilişki üzerine bir tartışma. Cumhuriyet Üniversitesi Edebiyat Fakültesi Sosyal Bilimler Dergisi, 34(1), 25-32.

$\mathrm{Yu}, \mathrm{C}$. ve Bastin, M. (2010). Hedonic shopping value and impulse buying behavior in transitional economies: A symbiosis in the mainland china marketplace. Journal of Brand Management, 18(2), 105114.

\section{Kaynakça Bilgisi / Citation Information}

Türk, Z. (2018). Hedonik ve faydacı tüketim eğiliminin plansız satın alma davranışı üzerindeki etkisi: Bir araştırma. OPUS-Uluslararası Toplum Araştırmaları Dergisi, 9(16), 853-878. DOI: 10.26466/opus. 474486 